監問 大内 偪島医大). $\mathrm{Mg}$ を使用された理由 と, “実験結果から考えられる $\mathrm{Mg}$ の意義. 応答 島 田和哉 (東崡大). 化骨に重要な元素として Ca，Sの他
Pがあるが，Pは Ca とほぼ同じ動きをとることが判明 している，化骨，骨破壊に対する $\mathrm{Mg}$ の動きが興味あ る元素でありながら判明していないので採用した。

B $79-1089-23860$

\title{
28. 内耳液の蛋白質分画に関する研究
}

\author{
○鈴木康之 ・伊藤明和・鈴木浩二 ・三宅 弘 (名古屋大学)
}

目的 内耳液が他の体液とは翼なった性蜇を有するこ とは既に知られた事寄であるが，内耳液蛋白翼に関して む同様であり，その組成は血清，脳春䯣液とも異なるも のである、今回，われわれは免疫学的方法を用いて内耳 液の蛋白質分画を検討するととるに，内耳液病態を知る 目的で実験的に中耳アレルギー性炎を惹起したときの蛋 白質分面の変動についても検討したのでその成績を報告 した.

方法 体重300 400グラム前後の有色モルモットの内 外リンパ液につマて, Agar immunoelectrophoresis Ag $\mathrm{Ab}$ crossed electrophoresis により蛋白質分画を分析し た. 次に中耳アレルギー惹起法であるが，卵白アルプミ ンにより動物を感作し，抗体価の上昇したものについて 中耳腔内に卵白アルブミンを注入すると，中耳粘膜はア ルサス反応による著しい楁出性炎症を生ずる，中耳腔注 入後, 30 分後, 24時間後, 10日後に内耳波を採取し,

$\mathrm{Ag} \mathrm{Ab}$ crossed electrophoresisにより泳動した. 一次 泳動により蛋白翼を分離した後，抗全血清添加 Agarose 中に移し，直角方向に泳動を行った.

成績 正常群のモルモットでは, 内外リンパ液とむ Agar immunoelectrophoresis では 4 本の沈降線, すな わち Albumin, Haptoglobin, Transferrin, r-Globulin 観察できた. Ag Ab crossed electrophoresis では外り ンパ液において，これらの沈降線以外に $\beta$-位を中心に数 本の沈降線が観察された，内リンパ液では $\beta$-位を中心に $1 \sim 2$ 本の沈降線が観察されるのみで外リンパ液よりも 出現する沈降線の数は少ない．次に中耳アレルギ一惹起 群の内耳液の泳動像について述べる.30分後の外リンパ 液で各淤降線は非常に強く染色され, 肉厚となる。陌 位を中心に対照群にみられない沈降線が出現する。 $\gamma$ Globulin は相対的に peak の位置が極めて上昇する.
Haptoglobin にもこの傾向がみられる，24時間後の泳動 像もこの傾向が観察されるが, $\gamma$-Globulin の peak は低 下してくる.

Haptoglobin の位置も低下し， $\beta$-位を中心に新たに出 現した沈降線も消失してくる.10日後の泳動像は対照群 と著変がなくなる.内リンパ液にも30分後の群では外り ンバ液と同様の変化がみられるが，その程度は軽く，24 時間後には回復傾向を示し，10日後の群では対照群と著 変はなくなる。

考按 内耳液蛋白翼の組成は低分子量蛋白である Albumin 等が多く, $\gamma$-Globulin のような高分子量蛋白は少 ないことが報告されており，今回の実験でもその傾向が あることが明らかとなった．中耳アレルギー薏起時にみ られた内耳液蛋白質の泳動像の变化は, 総蛋白量の増加 傾向に加えて，r-Globulin が著るしく増加することが明 らかとなった．これは内耳液の炎症性変化を示すもの で，中耳腔内に生じたアレルギー性次症が直接あるいは 間接に内耳にも波及して，以わゆる内耳炎の病態を表わ しているものと考えられる. 今回の実験ではアルサス型 の組織反応によるむので血管系の変化が主体であると考 えられ，内耳血管系の障害による血清蛋白質の漏出によ り蛋白分画の変化が生じたものと考えられる、これらの 変化は急性であり，24時間後にはすでに回復過程に入 り，10日後には正常の分画像を呈することが明らかとな った. 今回の実験により中耳局所の炎症性病変に対する 内耳液蛋白倎の態度についてその概要を報告したが，中 耳病変の内耳に対する影響は諸家の報告にみられが内耳 液蛋白質分画においても著明な変動がみられたことは， 内耳人の侵墏に対する内耳液体系の反応の一面を表わし ていると考えられる。 